\title{
Contesting moralities: the politics of wildlife trade in Laos
}

\author{
Sarinda Singh ${ }^{1}$ \\ University of Queensland, Australia
}

\section{Introduction}

Unregulated and illegal trade in wildlife has been characterized by conservation groups as a key and some suggest 'the greatest' - threat to remaining wildlife populations in Asia (Sautner et al. 2002, 2005; see also Redford 1992; Robinson and Bennett 2000). Indeed, the most comprehensive review of wildlife in one country, Laos, concludes that "[w]ildlife throughout [the country] is declining" and "[t]radedriven hunting is the major factor pushing wildlife species...to extinction" (Duckworth et al. 1999: 21-23). In this article I explore the representations of the wildlife trade that are popularized by those attempting to regulate this activity internationally and by conservationists, officials, villagers and traders in Laos. I consider global discourses, national policy formation and local patterns of trade as interconnected politicized social domains, which intersect materially and discursively (Li 2002). I draw upon the insights of recent political ecology studies of conservation, though this approach has yet to be utilized in studies of the wildlife trade (Adams and Hutton 2007; Delcore 2004; Gezon 2006; Jones 2006; Sodikoff 2007). Indeed, most studies have been done by conservationists (Ginsberg 2002; Nooren and Claridge 2001), political scientists (Miyaoka 2004; Stoett 2002, 2005) and policy makers (Dickson 1999; Favre 1993; Sand 1997). In these and other studies, localized patterns of trade, and international policy negotiations, have received much more attention than the interplay between them in specific national contexts (Arroyo-Quiroz et al. 2005). This is where political ecology's engagement with a diversity of disciplinary perspectives, and its attention to the multi-scaled politics of resource control, offers a valuable addition to an understanding of wildlife trade as a social and environmental concern (Forsyth 2003; Paulson et al. 2003). Many studies of conservation in political ecology and allied fields have focused on the social effects of protected areas (e.g. West et al. 2006). Attention to other key conservation initiatives, like wildlife trade regulation, seems critical for a broader understanding of conservation.

The Convention on International Trade in Endangered Species (CITES) provides for trade regulation and forms the centre-point of the global discourse of wildlife trade. ${ }^{2}$ With 171 states now having joined CITES, it is now one of the largest international conservation treaties. It is also considered to be at the forefront of modern conservation efforts (Ginsberg 2002). The promotion of regulation through CITES is based on substantial research indicating wildlife decline (e.g. Duckworth et al. 1999) and the biological limits to sustainable harvests of particular fauna (Robinson and Bennett 2000). In seeking to legitimate global conservation goals, unregulated wildlife trade is seen as unsustainable and immoral, in contrast to standardized regulation through CITES. Responding to such assertions, critiques of conservation, especially in developing countries, could argue that the imposition of global regulatory systems ignores local livelihoods and homogenizes diverse cultural identities in a manner that local practices understandably resist. Yet this critique tends to recreate an oppositional approach to the examination of international conservation efforts and their local effects. The immorality of unregulated wildlife trade is simply pitted against the unfairness and immorality of impositions by foreign conservationists (see also Lewis 2005; Miyaoka 2004; Sodikoff 2007). Scott's (1998) notion of 'simplification' - when extended to apply to non-state as well as state entities (Adger et al. 2001; Li 2002) - provides a useful way to move beyond such idealized contrasts of global hegemony and local resistance. Debates over cultural imperialism, sovereign rights and Western dominance are necessary to ensure more equitable global environmental policy. Still, such charges at times exaggerate the hegemonic aspects of international institutions and omit the hegemonic aspects of local institutions (Nygren 1999). International treaties, national policy and local practice are all subject to simplification when they are represented in popular discourses by proponents and opponents of conservation. A closer examination of internal complexity may enable a shift away from polarization to an increased collaboration by those who see trade in wildlife as an environmental and social concern (Tsing 2005).

The recent accession of Laos to CITES provides a valuable context in which to comprehend the dynamics permeating global conservation initiatives, national policy formation and local practice. This is particularly so because Laos is commonly imagined as subject to aid donor demands. This is due to its

1 Postdoctoral Fellow, School of Social Science, University of Queensland, St Lucia Qld 4072, Brisbane, Australia. s.singh2 "at" uq.edu.au. The research was supported by an Australian Postgraduate Award through the Australian National University, WCS, the Ministry of Agriculture and Forestry, Earth Systems Lao and most importantly, the many people who generously shared their knowledge and experiences with me. Detailed comments from Andrew Walker and three anonymous reviewers helped refine the arguments here. I also appreciate feedback from Arlyne Johnson, David Trigger and Mike Fabinyi at different stages in the writing. Any faults are solely those of the author.

2 The term 'wildlife' in the context of CITES refers to animals and plants yet my argument relates primarily to vertebrate animals as these are the animals implied by the Lao term for 'wildlife' (sat paa). 
status as one of the last least-developed countries in Southeast Asia. In order to demonstrate the intricacy of debates about wildlife trade without dichotomizing, I acknowledge the divergence between global conservation discourses and local practice but do not make this the focus of the article. Instead, this article considers the politicized debates within global, national and local domains. To begin, I examine global discourses on wildlife trade through an outline of popular representations circulating in the mass media and conservation literature. The remainder of the paper focuses on Laos, first considering the politics behind recent policy changes and then the local perspectives and patterns of wildlife trade. ${ }^{3}$ It is important to note that my understanding of national and regional politics relies strongly on the perspectives of foreign consultants because of the wariness and secrecy that surrounds discussions of the issue and politics more generally in Laos (Nooren and Claridge 2001, Stuart-Fox 2004). ${ }^{4}$

The outline of local patterns and perspectives of wildlife trade in the final section benefits from conservation ecology and ethnographic research. For the former, my background in ecology enabled me to contribute to conservation-oriented surveys of wildlife hunting and trade in rural areas of central (Khammouane Province, Bolikhamxai Province), southern (Attapeu Province), and northern Laos (Luang Namtha Province). These utilized structured and semi-structured questionnaires, market surveys, focus group discussions and key informant interviews with villagers, traders and officials (Johnson et al. 2004a, 2004b; Singh et al. 2006). For the latter, participant-observation methods were used during long-term residence in Vientiane and in Nakai District (Khammouane Province) as well as during shorter stays in other rural areas and provincial capitals. During the main period of fieldwork, I lived in a small dormitory for district forestry officials in the Nakai district centre for five months and then in a village near the district centre for one month (Singh, in press a). A subsequent consultancy in Nakai enabled a further two month stay mainly in the district centre, living and working with protected area officials and revisiting my former hosts. This multi-sited, opportunistic and non-systematic style of data collection - or what Tsing (2005: x) aptly refers to as "patchwork" ethnography - was largely a result of delays in obtaining research clearances. Still, it did enable discussions with a wide range of people across urban and rural locales. Some important issues I was not able to address include: (i) the perspectives of some important actors (e.g. current Lao decision-makers, large-scale wildlife traders); (ii) the perspectives of non-Tai ethnic minorities; ${ }^{5}$ (iii) surveys of wildlife ecology and, (iv) the social construction of 'wildlife' (but see Singh 2007). Hence, it is important to emphasize that my aim is simply to problematize notions of morality that are implicit in the conflicting representations of wildlife trade regulation that circulate amongst proponents and opponents of conservation.

\section{Contestation in the global regulation of the wildlife trade}

In this section I draw attention to the construction of international conservation discourses as an ongoing process of contestation. My contention is that significant internal inconsistency and uncertainty can be obscured in global conservation narratives. This creates an appearance of scientific and moral unity (Forsyth 2003; Wallington and Moore 2005). CITES is one of the longest established and most positively regarded multilateral environmental agreements, yet to be matched by comparable global agreements for forestry or biodiversity protection (Brack 2003; Ginsberg 2002; Sand 1997). ${ }^{6}$ Global conservation discourses typically assert that "CITES, is the largest, and perhaps most important wildlife conservation agreement in the world, and a vital tool to combat the threat to plants and animals posed by the international wildlife trade" (WWF 2007). Since it can purportedly achieve the protection to endangered species that unregulated trade cannot, this provides a moral justification for the imposition of such a universal regulatory regime. ${ }^{7}$ As part of the transformation to achieve sustainability, CITES is offered as a

\footnotetext{
3 The main period of fieldwork in Laos was from March 2003 to July 2005. This included an eight month volunteer placement funded by AusAID with the Wildlife Conservation Society (WCS) and six months living in Khammouane Province. Subsequent visits to Laos were made during 2006-07 as part of consultancies.

4 I use the generic term 'consultant' to refer to people employed by NGOs or projects that are funded by bilateral or multilateral donors. Further clarification is avoided to maintain some degree of anonymity, especially given the small size of the conservation sector in Laos. Over 30 consultants - mainly foreign but some Lao - who were working or had recently worked on conservation in Laos offered their ideas in repeated discussions about wildlife conservation. Over 50 other foreign consultants working in natural resource management (e.g. forestry, ecotourism, environmental consulting) and development (e.g. rural development, governance, hydropower development) also provided valuable information on contemporary and historical issues in Laos. Many other foreign and Lao consultants and officials were interviewed informally but provided less information that is relevant for this specific paper.

5 My work was primarily with Lao and other Tai ethnic minorities who are commonly referred to in Laos collectively as 'Lao Loum' and all belong to the Tai-Kadai ethnolinguistic group.

${ }^{6}$ CITES formally emerged at a meeting of members of The World Conservation Union, IUCN, in 1963 and entered into force 12 years later. CITES was preceded by colonial attempts to regulate trade dating back to the end of the $19^{\text {th }}$ century (Sand 1997).

7 The argument for international regulatory systems for wildlife trade is further supported by claims that while hunting practices may have been sustainable in the past, this is no longer the case (Robinson and Bennett 2000).
} 
superior alternative to unregulated wildlife trade, which is instead popularly associated with crime, disease transmission, biodiversity loss and animal cruelty (e.g. BBC 2004, 2007; CI 2004; Karesh et al. 2005; Pearl 2004; WCS and TRAFFIC 2004). Yet there is contestation within global conservation discourses. Moral and scientific unity is challenged by the divergence between popular representations of wildlife trade and the specific regulatory approach of CITES, and also by debates within CITES over different approaches to wildlife management. These two issues, which I briefly consider below, question the nominal ascendancy of CITES as a monolithic or unified regulatory system with unanimously accepted rules and norms.

First, the divergence between the popular imaginings of wildlife trade promoted by conservationists, and the actual regulations of CITES. In global conservation discourses, wildlife trade is most commonly represented as a threat that needs to be halted or controlled (Sautner et al. 2002, 2005). CITES meetings are thus publicized by phrases such as, "[n]ations meet to protect wildlife" (Black 2007) and "Southeast Asia seeks to crack down on animal trade" (Reuters 2007). When conservation organizations argue that "[w]hen the buying stops, the killing can too" (WildAid 2007), they promote a negative depiction of all forms of trade and an implication that CITES seeks to prevent all such activity. For instance, proponents of CITES consider the case of wildlife "such as the tiger and elephants" - which are the focus of strict and well publicized trade bans - as making "the need for such a Convention seem obvious" (CITES 2007). Despite the use of charismatic, rare and totally protected species like these as mascots, most of the 33,600 species of animals and plants covered by the Convention are not endangered ${ }^{8}$ and CITES recognizes this by according varying levels of protection to species grouped into three distinct lists. ${ }^{9}$ The requirements and procedures for regulating wildlife trade vary according to which Appendix a species is listed in, with the vast majority (97 percent) in the Appendix that permits regulated trade, and only a small proportion (2 percent) listed as totally protected and endangered. Hence, in practical terms, CITES is far from being a policy instrument capable of prohibiting all wildlife trade since only a minority of listed species are subject to strict trade restrictions. While the role of CITES is to selectively regulate, rather than prevent all trade in wildlife, the distinctions between regulation and control on the one hand and prohibition and bans on the other are blurred in popular representations of the issue that tend to vilify all wildlife trade. ${ }^{10}$

The second related issue that challenges the image of CITES as a scientifically unified and coherent regulatory system is the persistent debate over different approaches to wildlife management. While utilitarian values have historically been a key concern motivating global wildlife trade regulation (Sand 1997) and CITES has made increasing formal commitment to the ideal of sustainable use (CITES 2007), significant internal debates persist around the fundamental valuation of trade. This ongoing, behind the scenes conflict results in a broad divide in the international conservation arena between those who regard trade as a "conservation tool" and those who regard trade as a "potential threat" (Ginsberg 2002: 1185). ${ }^{11}$ The tensions between pro-trade and anti-trade approaches to wildlife management mean that CITES has been likened to a forum where members of opposing camps launch ideological crusades against each other (Stoett 2002: 197). Differences between pro-trade and anti-trade approaches to wildlife management are exacerbated in developing countries where poverty alleviation dominates local concerns. Since trade regulation affects the use of natural resources, any international system that seeks to regulate trade is inextricably tied to arguments over national sovereignty. ${ }^{12}$ An ongoing challenge for CITES is actually achieving outcomes that will ensure the sustainability of wildlife trade while avoiding accusations of cultural imperialism (Arroyo-Quiroz et al. 2005; Ginsberg 2002; Hutton and Leader-Williams 2003; Stoett 2002).

The overall positive view of CITES in the global conservation arena partly arises from the flexibility and range of the Convention, which allows both anti-trade and pro-trade perspectives to be encompassed

\footnotetext{
'Endangered' according to IUCN's Red List of Threatened Species (IUCN 2007).
}

9 Appendix I of CITES includes species threatened with extinction, so trade is rarely permitted, Appendix II species are less threatened with extinction but require regulation of trade to ensure that utilization does not exceed sustainable limits, and finally, Appendix III contains species that are protected in at least one country, which had requested other CITES parties to assist in controlling trade (CITES 2007).

10 Even some conservationists argue that "[b]ushmeat is too often presented by our popular press as something akin to a drug trade in which the weak and immoral indulge. Those who study or observe the bushmeat trade in Africa know that it cannot be so easily categorized" (Brashares 2006: 365; see also Bell et al. 2007).

11 To clarify the former perspective, trade is posed by some as a 'tool' that can achieve conservation outcomes through providing incentives and benefits for people to be encouraged to use resources sustainably. This approach is most often suggested in contexts where people are dependent on natural resources for their livelihoods. For examples of pro-trade views in the conservation literature see Lewis and Alpert (1997), Hutton and Leader-Williams (2003) and Cooney and Jepson (2006) while a contrasting view is provided by Thorbjarnarson (1999) and Geist (1988). Anti-trade approaches form strong lobby groups in Western countries and have been heavily influenced by animal welfare interests (Miyaoka 2004). At the opposite extreme to anti-trade conservationists are anti-CITES free-market advocates (e.g. De Alessi 2003).

12 Recently, this has drawn CITES into controversy about its role in the regulation of trade in endangered timber and fish species (Brack 2003). 
within its ambit. This does mean however, that while CITES is publicly promoted as a morally and scientifically legitimate necessity, the Convention is continuously challenged by internal tensions. Varied pro-trade perspectives are commonly aired within CITES forums (Favre 1993), however, anti-trade views are strong in the public domain. Charismatic species of wildlife, such as elephants, tigers and whales, are symbolic of trade bans as they are often featured in international discourses as symbols of 'wilderness' and 'nature' that should be completely protected (e.g. Lewis 2005; Miyaoka 2004; Stoett 2005). Furthermore, public fears about criminal activity and disease risks can be harnessed to support strict anti-trade views in the name of conservation, even while other conservationists decry such suggestions. ${ }^{13}$ Regulation of wildlife trade, though based on scientific expertise, must be recognized as a value-laden issue, an assertion of how people should behave and why (Arroyo-Quiroz et al. 2005; Bell et al. 2007; Dickson 1999; Miyaoka 2004; Stoett 2002). The debates over values within CITES brings into question public understanding of this system as a united moral and scientific system, and it cautions against critiques of conservation that are based on such representations. Global conservation discourses may have aspirations that can appear universalizing or hegemonic, but this does not necessarily mean that associated regulatory frameworks have the exactly the same tendencies or even capabilities.

\section{Explaining policy changes in Laos}

The remainder of this paper examines the situation in Laos in order to comprehend the local dynamics that surround the extension of global conservation initiatives. This section explores recent policy changes regarding wildlife trade in Laos to demonstrate the critical role of regional and national political interests in shaping the country's conservation commitments; first, in relation to international regulation in the form of CITES and second, through consideration of national policy formation. By granting more attention to domestic politics I bring into question any simplistic contrasts between global and local concerns. In doing so, I do not deny the influence of international conservation interests in shaping policy in developing countries (e.g. Arroyo-Quiroz et al. 2005; Sand 1997). Yet I do question critiques of conservation that overly emphasize the hegemonic aspects of international institutions. For instance, Goldman (2005: 189) writes of Laos being under "tremendous pressure" from the "international development community", especially the World Bank, to be made into an "environmental state" simply because, "[t]o access capital, borrowing countries must play by the rules of these higher authorities." While the following analysis is not inclusive of all political concerns that contribute to policy formation in Laos, it does clearly show how international relations are more intricate than the conservation interests of 'wealthy' Western institutions and the development aspirations of 'poor' countries.

\section{CITES and the importance of regional politics}

In March 2004 Laos joined CITES, the last nation to do so in the group of ten countries comprising the Association of Southeast Asian Nations (ASEAN). The Lao government was commended at international conservation forums, including the next CITES meeting held later in Bangkok (TRAFFIC 2004b; TRAFFIC and WWF 2004; WCS and TRAFFIC 2004). This October 2004 meeting was considered particularly significant as it was the first time parties to CITES had convened in Southeast Asia, an area regarded as a global hub for wildlife trade (World Bank 2005). The meeting was also used to launch a joint NGO-ASEAN initiative that aimed to increase regional cooperation in addressing wildlife trade issues (TRAFFIC 2004a). A month later in Bangkok, IUCN's World Conservation Congress followed the CITES meeting and drew up additional agreements relating to wildlife trade in the region (Anon. 2004; Tung 2004; World Bank 2004). By December 2005, ASEAN representatives jointly released the ASEAN Statement on Launching of the ASEAN Wildlife Law Enforcement Network (ASEAN-WEN) (ASEAN 2005). The new unity in endorsing CITES, along with the initiation of related regional agreements, has been promoted at international forums as steps towards a concerted effort to fight the illegal trade in wildlife, "[s]ignaling a new commitment to combating this problem" (World Bank 2004). One international conservation organization asserts that "[f]ollowing Lao PDR's accession to CITES...for the first time [ASEAN nations] have a common basis upon which to conduct legal and sustainable wildlife trade" (TRAFFIC 2004b). They considered this "a hugely positive step forward" (TRAFFIC and WWF 2004: 1).

Hence, at a policy level there appears to be an increasing congruence between the interests of the Lao state and the objectives of CITES, as both aim for sustainable use of biodiversity for conservation and development benefits (GOL 2004; IUCN 1998). Yet conservationists working in Laos tend to regard the Lao accession to CITES with more ambivalence. Many question the state's bureaucratic capacity to deal with the additional regulations and reports that are required to implement the Convention. One foreign conservationist argued that Laos' accession to CITES is irrelevant, pointing out that all surrounding

13 For example, some conservationists used recent concerns about avian influenza to argue for a continuation of the European Commission's 2005 moratorium on all wild bird imports. This prompted contrasting views from conservationists opposed to such bans (Cooney and Jepson 2006). 
countries have been signatories for nearly a decade so technically unregulated wildlife trade out of the country is not legal anyway (see also Nooren and Claridge 2001; Srikosamatara and Suteethorn 1994; Yongge 2000). He said, "but it's still all going on and demand is often from those surrounding countries and CITES hasn't changed that." The accession to CITES is commonly interpreted by conservationists within the country as an indicator of "international pressure" rather than a demonstration of state commitment to sustainable use of biodiversity. The discrepancy between policy commitments and practice is not surprising considering that CITES meetings are themselves often dominated by matters of politics and economic matters, despite the public appeals for conservation (Arroyo-Quiroz et al. 2005). Experienced CITES observers are well aware of the dominance of politics at international conventions (Favre 1993: 901). Yet the political dimensions of international policy are less publicly advertised. ${ }^{14}$ While politics dominates discussions inside CITES forums, this is not how CITES is usually represented in the public arena. In order to legitimate it, politics is elided and policy commitments are justified by the concerns for conservation and sustainable development.

An awareness of the disjunction between public policy statements and political motivations raises the question of why Laos joined CITES in 2004. In considering this question it is crucial to maintain awareness of conservation as a significant but historically dynamic influence. Conservation projects have been making recommendations for Laos to join at least since the early 1980s (Sayer 1983: 31). A former forestry official from Vientiane described how he had worked with the support of conservation organizations on a proposal for Laos to accede to the Convention, about 15 years before Laos finally joined (see Nash and Broad 1993). He told me that the Lao government rejected the proposal at that time because of concerns over the small size of the Department of Forestry and its limited organizational capacity as well as a lack of funds for implementation of the Convention - all common concerns with CITES in less developed countries. In the late 1990s, Laos was reportedly considering CITES membership with the support and encouragement of international conservation organizations (Duckworth et al. 1999: 1). A gradual accumulation of pressure from conservation groups may thus seem to account for Laos' final acquiescence in 2004. Yet conservation projects in Laos actually were at their peak during the 1990s, collapsed in 2000 and gradually started to re-emerge a few years later (Anon. 2000; Fujita 2004; Singh 2007). Evidently, pressure from conservation interests was not primarily responsible for the state's recent accession to CITES. Not only did Laos counter recommendations from conservationists and donors to join CITES for over 25 years, the Lao government resisted joining CITES during the decade when the influence of conservation was strongest and instead joined when it was domestically quite weak.

More important than conservation concerns is the standardization of trade regimes required for ASEAN. Regional agreements, such as plans to achieve free trade between ASEAN countries by 2008, create significant incentives for standardization of trade regulations including those relating to wildlife (Bourdet 2000). The ASEAN-WEN initiative launched in 2005 had as its opening statement: "[r]ecognizing that each Member Country of the Association of Southeast Asian Nations (ASEAN) is also a Party to the Convention on International Trade in Endangered Species of Wild Fauna and Flora (CITES)" (ASEAN 2005). Laos had to become a member of CITES before the launch of ASEAN-WEN could occur. The director of a conservation organization based in Thailand explained that Thailand pushed for the ASEAN-WEN agreement because "they want to be seen as the leader in an ASEAN context....and once they make commitments at meetings then Indonesia pressures them to stick to it." ${ }^{15}$ He also said how wildlife trade is seen as an 'easy' environmental problem to prove their green credentials to Western countries in comparison to illegal logging or industrial pollution, "they don't want to have to change or regulate their industries."

This apparently worked, and in September 2005 the USA established the Coalition Against Wildlife Trafficking (CAWT), now with 19 member governments and NGOs. At the launch of CAWT during a wildlife film festival in USA a government representative presented the popularized view of wildlife trade as a pervasive, criminal threat to biodiversity and public health (US Department of State 2005). The initial focus of CAWT activities was ASEAN with USA providing funds to support wildlife trade enforcement activities. A USA official thus stated: "[w]e were very instrumental in the formation of the world's first regional Wildlife Enforcement Network, ASEAN-WEN" (US Department of State 2007). Through funding and regional agreements the simplified representations of wildlife trade have practical effects and influence beyond their source. Hence, I do not wish to assert, as some political ecology research has, the "irrelevance" of international discourses in "explaining dynamic local power relations and environmental

14 For instance, one foreign conservationist - an experienced field biologist but only first-time attendee at the Bangkok CITES meeting in 2004 - remarked his surprise at seeing how the substance of negotiations were trade deals, and vote swapping to secure national interests.

15 The use of wildlife trade in regional politics was also publicized in a recent dispute over orang-utans that were reportedly smuggled from Indonesia and/or Malaysia to Thailand. One reporter writes that the orang-utan issue entailed "a loss of face for Thailand in the run-up to a meeting of [CITES], which is to be held in Bangkok this autumn. In preparation for the convention, Thailand has been promoting a 'green' image in attempt to mask its notoriety as a wildlife smuggling centre" (McGirk 2004). 
outcomes" (Adger et al. 2001: 689). Rather, I argue that Laos' national policy formation is strongly influenced by interactions between regional and international political interests.

\section{Local intricacy in policy formation}

In this section I consider recent changes to Laos' national policies on wildlife trade regulation. I aim to further elucidate some of the varied political concerns that affect policy in the country, and hence argue against a view that sees international conservation interests as a successful hegemony. International organizations do have considerable influence in modern-day Laos, a country that was highly dependent on foreign aid through most of the $20^{\text {th }}$ century (Bourdet 2000). Laos also lacked an active and empowered civil society, due to the leadership of the Lao People's Revolutionary Party over the last three decades (Stuart-Fox 2004, 2006). This means that national policy formation is, rather, strongly linked to interactions between the state and international interests. ${ }^{16}$ This is particularly the case for environmental management as its funding is dominated by foreign sources (Clarke 1999). Official policy then provides a framework that international agencies utilize to assert the legitimacy of their concerns. For instance, conservation organizations in Laos have usually focused on the illegality of wildlife trade in their awareness-raising programs. Signs at markets, stickers on motorbikes and songs sung at public festivals declare that "buying and selling wildlife is against the law." Despite such appeals to a rule-of-law, state policy is rather opaque, consisting of a multitude of written laws that often overlap and even conflict (Anon. 2000; Stuart-Fox 2004, 2006). In addition, there are unwritten policies that are only discussed in closed political meetings for government officials, selectively disseminated to non-Party members and villagers and guessed at by international organizations. The ambiguity in Lao policy formation and implementation brings into question any simplified assumptions about the power relations between international and local institutions.

The influence of international conservation discourses, and the limits to this influence, was well demonstrated during recent negotiations between the Lao government and international agencies over policy regarding wildlife trade. The regulations issued in 2001 maintained that all sale and purchase of wildlife was illegal (Article 17, MAF 2001). They also designated a minority of 'restricted' species, for which hunting was illegal, while the majority of species were designated as 'managed' or non-protected species that could be hunted for local consumption by villagers. These articles together meant that any hunting for trade was illegal as was any hunting of the protected species. Hunting non-protected wildlife species for subsistence use was legal (Singh in press b). In December 2003, the Lao government revised the regulation in response to World Bank pressure to demonstrate its broader commitment to environmental management (MAF 2003). Though unacknowledged in policy documents this was widely admitted by consultants and government officials to be linked to the project assessments made for the Nam Theun 2 (NT2) hydropower scheme. This US\$1.5 billion project is being promoted by the Bank as a flagship project for beneficial economic, social and environmental outcomes achieved through large-scale infrastructure development (ADB 2004; Goldman 2005; World Bank 2005; see also IRN 2004; Ryder 2004). Revision of the laws concerning wildlife was deemed important by the Bank because commercial hunting and wildlife trade have been identified as significant issues for achieving effective management in the project zone, and particularly in the Nakai-Nam Theun National Protected Area (IUCN 1999; Johnson et al. 2004b; Nooren and Claridge 2001; Robichaud 2002; Scudder et al. 1997). ${ }^{17}$ In 2004, a conservationist discovered that the article relating to the ban on all wildlife trade was completely omitted in a 2003 revision of the regulations (MAF 2003). This means that only protected wildlife are now subject to a trade ban, given that they are still prohibited from any hunting or use. In contrast, in written law nonprotected common types of wildlife are no longer subject to any trade restrictions.

While municipal government representatives in Vientiane were themselves confused as to the 'real' policy when the issue was raised by international organizations, central government officials later made assurances that the omission of the trade ban in the revised law was an accidental oversight. District forestry officials - the lowest ranking officials and most distant from policy centre of Vientiane - are largely unaware of the 2003 revision and continue to assert that all wildlife trade is illegal, as do some reports from international donors (e.g. ADB 2004: 9; Singh in press a). Conservation projects continue to assert the illegality of all wildlife trade even though this is not actually the case under the 2003 law. A conservation organization working on wildlife trade in the capital city was informed by the central government that they should simply continue their project. This is even though the activities they undertake, like confiscation of wildlife from market sellers and its public destruction, relate primarily to species that are not banned from trade under the existing legislation since protected species are rarely observed at public markets in Vientiane. Despite assurances from officials, some conservationists in Laos

16 This is also a key reason for the absence of the strong 'grassroots environmentalism' found in neighboring Thailand (see Delcore 2004).

17 Many endangered species that conservationists believed require protection are not listed as 'restricted species' while other common species are listed (Duckworth et al. 1999: 25). A similar problem challenges CITES (Ginsberg 2002). 
are not sure if the change in the law was a deliberate shift in policy as after a more than a year there was still no sign of amendment. This shows how written law cannot be equated with government policy, and also that at the very time Laos was acceding to CITES, its domestic policy regarding wildlife trade was very uncertain.

During the early 2000s some government officials continued to question conservationists over the validity of banning wildlife trade. For instance, one forestry official in Vientiane pointed to the economic value of many wildlife species in Laos, the poverty of rural people and the scarcity of other income sources for them (see below). A common perspective among officials is that protection of natural resources would be best achieved by undertaking rural development activities, the premise being that this will reduce villagers' reliance on natural resources. Hence, the head of a District Agriculture and Forestry Office in Attapeu commented depreciatingly on an ongoing conservation project in a nearby National Protected Area, implying that it would be unsuccessful because the project was not doing any rural development activities. He explained that, "if you want to protect the 'environment' (singweetlom) then you need to give villagers livelihood activities because now they rely on 'nature' (thammasaat)." In this view, development is a precondition for conservation, and conservationists' concerns about the extent of wildlife trade are seen as opposed to development and to villagers' well-being. ${ }^{18}$ Wildlife conservation is often far from being regarded as an appropriate aim or essential component of sustainable development. Rather it is an indirect outcome or possibly even an impediment to the development agenda.

Yet this contrast between foreign conservation interests and Lao desires for development is a politically acceptable simplification (Anon. 2000; Yongge 2000). A crucial element that is always evaded in policy documents and in discussions with most government officials is the relationship between Laos and its neighbors. This is again evident in discussions about NT2 and a series of attempts to negotiate transboundary conservation agreements (Anon. 1993; IUCN 1998; UNDP 1993, 2003). NT2 is situated near the Annamite Mountain Range that forms the border region of Laos and Vietnam. This area is recognized as a global biodiversity hotspot by conservationists and the Lao government had thus been advised by international organizations to nominate the area for World Heritage listing (Scudder et al. 1997). A representative of IUCN, which advises the World Heritage Committee about new listings, explained that IUCN would only recommend the area be considered if both Laos and Vietnam cooperated in transboundary management, in part because of the "significant transboundary issues." A villager living near the Lao-Viet border in Khammouane explained to me how Vietnamese come to Laos to use traps to catch wildlife and collect other valuable forest resources "but Lao people do not go to Vietnam because Lao people are scared, Vietnamese people will get angry with them." A conservationist remarked similarly, "at any time there are hundreds more Vietnamese than Lao people on the Lao side poaching wildlife" so, as another said, "it's no good Laos talking about management if Vietnam doesn't."

In the mid-1990s there was some cooperation between Lao and Vietnamese provinces in management of the Annamites (Duckworth et al. 1999; IUCN 1998; UNDP 1993). This stemmed partly from trade concerns and a local interest in revenue generation, as forestry and border officials tend to look for controlled goods that that can tax. Some Lao district officials also complain of how Vietnamese poachers come to Laos without any money so if they are caught the Lao authorities have to pay to feed them while they are in jail. All they can do is send them back to Vietnam, which also costs money, and villagers report that the same Vietnamese people often return after deportation (Johnson et al. 2004b). Though rectifying this evasion of taxes and fines, the provincial level cooperation reportedly soon stalled because of conflict with national interests, in particular the "special relations...[and] traditional friendship, special solidarity and comprehensive cooperation" (VNA 2005a) that is constantly referred to in the statecontrolled media. As one long-term consultant noted, this relationship "is only really between the upper echelons. It isn't something Lao or even Vietnamese people relate to. But those in the top wouldn't be where they are if it wasn't for the Vietnamese." Statements like this refer to the critical role of Vietnamese support in securing the ascendancy of the current regime following the Indochina War (Stuart-Fox 2004).

In the late 1990s, an international project on transborder management of the Annamites (IUCN 2000), in the words of one conservationist, "went the way of most attempts at transboundary protected areas - study tours, discussions, an agreement signed with objectives so broad that nothing is ever achieved." At a meeting about border markets, Lao and Vietnamese officials noted that "cross-border trade is an important part of the two countries'...relationship" (VNA 2005b). As this relationship is often seen to be based on exchange of natural resources from Laos for the technical and financial backing of Vietnam (Stuart-Fox 2006), it is not surprising that externally-driven attempts at redefining management of natural resources in the area encounter some complexities. The pre-eminence of political relations over conservation concerns was clearly demonstrated in 1999 when a Lao forestry official chairing a meeting stopped a representative of a conservation organization in mid-presentation and told him that he was not allowed to mention 'Vietnam' again in the meeting, he instead had to refer to "our neighbors to the east." The conservationist explained to me later that "because Vietnam is a political ally then it means there are

18 Elsewhere, I show how these discourses of villagers as reliant on nature, which are popularized amongst Lao government officials, are also used to blame villagers for forest decline (Singh 2007). 
no problems. It's the triumph of policy over reality." Similarly, another conservationist revealed how a recent book on bird habitats in Laos, "had to have the threats watered down to suit government requirements. Like for one area it mentioned transborder trade issues as a threat but they couldn't actually write 'Vietnam'."19

A second attempt at transboundary management in the same area was initiated in July 2004 and eventuated in an action plan to control illegal transboundary hunting, trading and transporting of wildlife (Anon. 2004). This action plan was one of the agreements released at the World Conservation Congress held in Bangkok in November 2004, six months after Laos joined CITES and a month after the CITES meeting was hosted in the same city. This action plan is considered more successful than earlier agreements because the Vietnamese delegation acknowledged that illegal wildlife trade was a problem. The Lao-Viet agreement actually followed on the heels of the Vietnam's 'National Action Plan to Strengthen the Control of Trade in Wild Fauna and Flora', which was issued just a fortnight earlier (Tung 2004). An observer considered that "the Lao side couldn't admit that there was a problem until the Vietnamese side did." In addition, the World Bank's support of the current efforts to manage transboundary wildlife trade came at a time when it was preparing for appraisal of the NT2 project and important concerns were the Lao government's commitment to conservation of biodiversity and safeguarding against anticipated criticism of the project (IRN 2004; Ryder 2004; World Bank 2000, 2004b).

Thus, national policies that are intended to regulate the wildlife trade in Laos are subsumed by regional and domestic politics, as well as locally embedded negotiations with international organizations, the broader re-engagement of the World Bank with large-scale hydropower development, and the pressure the Bank receives from other international organizations. In some ways the Annamites is distinctive in Laos since the involvement of the World Bank in NT2 and the importance of NT2 for the national economy ensured that resulting policy changes gained national salience. Yet this underscores the point that even considerable pressure from the Bank does not necessarily mean that developing nations immediately and absolutely succumb to their demands. While international agents from developed countries conservation and development oriented - do affect national legislation in less developed countries, they are not necessarily the only foreign interests with influence. Indeed, in Laos the frequently unacknowledged influence of Vietnam is considerably stronger than the influence of conservation organizations (Stuart-Fox 2004). ${ }^{20}$ Sovereign rights over wildlife and decisions to exercise those rights operate within politically circumscribed spaces that are heterogeneous products of history and of natural environments (Yongge 2000). Analyses of institutional power relations that fail to recognize the contingency of power are simplifications that do not do justice to the complexity that actually shapes local governance.

\section{Representations of the wildlife trade in Laos}

Lastly, I shift the focus from the policy that regulates wildlife trade to the norms that shape practice and popular discourses in Laos. CITES is not discussed much by the people I met, simply because aside from a few forestry officials in Vientiane who had worked on wildlife conservation projects, they had not heard of it. First, I briefly outline changes in recent years to the patterns and meanings of wildlife trade that have accompanied a decline in wildlife abundance, changes to wildlife use and the introduction of contemporary conservation efforts. Then I consider in more detail the perceptions of moral rights that surround wildlife trade in Laos today - what I call the rights to livelihoods and the rights of elites. ${ }^{21}$ I suggest that narratives of wildlife trade popular with most Lao people - wildlife trade as essential for Lao livelihoods, conservation as opposed to all forms of wildlife use, wildlife consumption as a part of Lao lives - simplify the complexity of local practice in a manner that evades the most unsustainable and inequitable form, that of the country's elites.

\section{Transformations of the wildlife trade in Laos}

Wildlife trade and exchange in Laos and with its neighbors is a historically embedded activity. Wildlife has long been part of regional trade and exchange networks, used as tributary payments to rulers and also as ritual gifts. ${ }^{22}$ For instance, during the pre-colonial era, tribute to Lao as well as Siamese, Vietnamese and Chinese leaders was often in the form of valued types of wildlife (Ngaosrivathana and Ngaosrivathana 2001). While the values and uses of wildlife show continuity with the past, the scale and

19 Other major reports evidence the same tendency (e.g. World Bank 2000).

20 The emphasis here on Lao-Viet relations stems from my fieldwork near the Lao-Viet border in Khammouane. The politics of wildlife trade is also closely connected to Laos' relations with Thailand and China (e.g. Yongge 2000).

21 I use the term 'elites' since this broadly corresponds to the Lao term phu nyai, literally meaning a 'big person'.

22 This is indicated by specific historical accounts (Bock 1985; Garnier 1996; Halpern 1958, 1964; Izikowitz 1979) as well as reviews of historical patterns of trade (Duckworth et al. 1999; Fujita 2004; Nooren and Claridge 2001; Walker 1999). 
extent of wildlife trade has increased, and biologists now consider wildlife trade a key conservation issue for Laos. ${ }^{23}$ The extent of this concern can be seen in the remark of one that "the sheer volume of wildlife trade makes you wonder how there's anything left at all" (see also Duckworth et al. 1999). These altered patterns of wildlife trade and abundance are reflected in altered patterns of local consumption. For instance, when a village trader in Nakai received a surreptitious delivery of a muntjac deer (Muntiacus muntjak) concealed in a rice sack that was quickly carried into the trader's kitchen by the motorbike driver she told me that it was the largest female she had seen for a long time. The most common type of mammal eaten in the village are rats and squirrels simply because there are few deer left. High-value wildlife, like other forest products, are increasingly sold by villagers rather than consumed locally (Bouahom et al. 2004; Johnson et al. 2004a). Large animals or species that command a high price in distant markets also tend to be excluded from village diets. Villagers in Attapeu thus described how they used to eat turtles "because there were no buyers", but now they always sell turtles to buyers who come to their village.

Wildlife trade continues today in Laos because of international and local demand for wildlife meat as well as for pets, traditional medicines and decorations (Coggins 2003; Nooren and Claridge 2001; Srikosamatara and Suteethorn 1994; Yongge 2000). The international trade in high-value wildlife is hidden and exclusive, similar to the timber market. In contrast, the most obvious form of wildlife trade is the public, small-scale sale of rodents (e.g. squirrels, rats, porcupines), birds, monitor lizards, wild pigs and other common species for their meat. The further one travels from urban centers the more common this trade becomes. Villagers often set up roadside stalls along main roads to sell wildlife to passing traffic along with garden produce and snacks. Despite such widespread and public trade in common types of wildlife, this activity has been sensitized by local awareness of foreign conservation concerns. In Laos today, particularly as a foreigner, it is difficult to even ask any questions about wildlife and not be viewed with suspicion. In Vientiane, market sellers are usually reluctant to have photos taken of wildlife they are publicly selling. Often sellers sternly say "you can not do that" (bo dai, bo dai), in stark contrast with the joking banter that is the norm in markets. In general, Lao people do not demonstrate the emergence of 'eco-rationalities' in accordance with the prerogatives of international agencies (Goldman 2005). Rather, responses of fear, disparagement and humor show how Lao people perceive conservation - including the promotion of anti-wildlife trade policy - as opposed to their own interests, and accordingly they resist it (Singh 2007).

As discussed earlier, current government practice generally follows the 2001 rather than the 2003 law, thus allowing rural villagers to hunt common species for subsistence while hunting protected species and hunting for trade are prohibited. Conservationists support this practice and argue that wildlife is a resource to be protected for villagers' consumption (e.g. Krahn and Johnson 2007; Sautner et al. 2002). Yet a remarkable caution surrounds all forms of wildlife use and it is commonly asserted by villagers, and even some district officials, that all hunting of wildlife is illegal (see also Nooren and Claridge 2001). Popular representations among Lao people thus frame conservation as opposed to hunting and trapping. The sensitization of wildlife use - while owing something to the impacts of the Indochina War ${ }^{24}$ - was undoubtedly enhanced by the initiation of conservation activities in Laos during the 1980s. At the time, trade was being rapidly transformed due to macroeconomic reforms initiated in 1986, which emphasized a shift from a centrally planned to a market economy (Bourdet 2000). In the same year as these broader changes in governance aimed at market liberalization, trade in all wild animals was prohibited (Nooren and Claridge 2001), meaning that Laos' national laws were stricter than the CITES convention it had yet to ratify. A forestry official in Vientiane explained how initially "the rule was very strict. Any type of trade was banned because it was easier to manage." Only in the 1990s were changes made to distinguish between different categories of wildlife, with varying levels of protection in a manner akin to CITES. ${ }^{25}$ Thus, conservation in Laos was from the outset associated with strict bans on all wildlife trade, which contrasted with the rhetoric of market-driven development being promoted for most other aspects of the economy. This supports a local view of development as requiring trade, conservation as anti-trade and hence, conservation as anti-development (Singh 2007).

The 1990s was the peak of conservation projects in Laos, as well as a time of major political and socio-economic shifts. Market liberalization was revitalizing the local economy and was interlinked with

23 For instance, lists of gifts between Lao, Siamese and Vietnamese dignitaries in the $19^{\text {th }}$ century "reveal how much living conditions at that time were, even for the upper class, somewhat Spartan" (Ngaosrivathana and Ngaosrivathana 2001: 126). Wildlife and wildlife products (e.g. elephant tusks) were important as gifts though this account suggests the scale of exchange was relatively limited. Halpern (1958: 82-83) makes a similar observation of northern Laos and the former royalty of Luang Phabang in the mid-20 ${ }^{\text {th }}$ century. In contrast, Nooren and Claridge (2001) describe how the contemporary scale of wildlife trade throughout Laos has expanded enormously.

24 In many areas of Laos, villagers relied heavily on forest foods during the war because of bombing of fields. The influx of arms (Duckworth et al. 1999) and population movements (Fujita 2004) were also significant factors affecting patterns of wildlife use and wildlife abundance.

25 Wildlife trade was still banned but the punishment was adjusted according to whether the species was protected as an endangered species or not. 
improved relations with China and Thailand (Walker 1999). Much of the high-value wildlife trade is directed towards neighboring countries as their increasing affluence, locally depleted wildlife populations and popularity of wildlife for use as food and medicines means that fauna and their derivatives fetch high prices (Coggins 2003; Nooren and Claridge 2001; Srikosamatara and Suteethorn 1994; Yongge 2000). Thus, observers consider the trade to have increased substantially during the 1990s despite the expanding presence of conservation projects that were attempting to achieve the opposite. Wildlife trade did however, become more discrete as protected species disappeared from public display, animals were hidden away under tables in markets, and were not advertised on restaurant menus. A conservationist working in southern Laos during the 1990s said how "we initially saw lots of wildlife in markets and then it very quickly disappeared, like in only six to twelve months. At first we thought this was positive, that our message was getting across but actually it had just gone undercover." He explained how local people recognized their faces, remembered them taking photographs of animals displayed for sale and learnt to hide the wildlife away when they came. The material transformations of wildlife trade - in response to changes in trade opportunities, wildlife abundance, conservation and regulation - have thus been accompanied by transformations in the social meanings of this practice.

\section{Representing the morality of the wildlife trade}

In this section, I argue that that Lao people in general do not regard the wildlife trade to be an immoral activity; it is a part of everyday life and a part of Lao identity (see also Bell et al. 2007). Furthermore, I suggest that two underlying norms contribute to this perception of wildlife trade as a moral right - the rights to livelihoods and the rights of elites. These rights are reflected in two broad types of wildlife trade. Small-scale trade signifies consumption, and the rights to livelihoods, while high-value wildlife trade - that is, trade in protected species or in large volumes - is associated with the rights of elites. Relevant for both is the desirability of wildlife consumption. ${ }^{26}$ The morality of wildlife trade is justified in local discourses that posit rural livelihoods in opposition to conservation. The perceived illegality of all wildlife use is so far removed from the daily interests and practices of villagers that it obviously requires lip-service and nothing more. This common perception draws on an idea of foreign conservation as opposed to Lao interests, and allows a space for elites to exert their authority over wildlife in preference to a conservation agenda.

Eating wildlife, and other wild caught foods, is part of villagers' moral right to sustain their livelihoods and this also provides a justification for the wildlife trade. ${ }^{27}$ Development discourses in Laos currently promote integrated approaches that consider subsistence and income-generating activities as interdependent aspects of rural livelihoods. This is the approach taken by villagers when they refer to their 'livelihoods' as haa yuu haa kin, literally 'looking to live, looking to eat'. Trade may be dominant in times of plenty while subsistence may dominate in times of need, or these uses may shift in response to changes in value and availability of wildlife species (Bouahom et al. 2004; Duckworth et al. 1999; Halpern 1958; Singh et al. 2006). Yet this integration is actually opposed by legal separation of wildlife use into supposedly discrete categories of permissible subsistence and forbidden trade. ${ }^{28}$ While a legal distinction may be drawn between consumption and trade in wildlife, Lao perceptions often ignore such distinctions. A district forestry official in Nakai implied this when explaining a poster titled 'Threatened wildlife species of Lao PDR'. While most of the pictured species are regarded by conservationists as uncommon food items and primarily threatened by trade for international markets, the forestry official instead explained the title by saying, "it means that if we keep eating them then they will all be gone." Lao people consuming wildlife is then posed as the fundamental use of wildlife, irrespective of the role of trade and the end user.

When wildlife use is equated purely with consumption, this allows a blurring between the subsistence needs of rural villagers and the luxury desires of urban residents. A Lao man in the provincial capital of Khammouane told me that "eating wildlife is normal in Laos", and as a Lao woman in Vientiane explained, "many people eat wildlife, so the trade is very large." Most significantly, village 'tradition' legitimates the morality of a modern urban practice, even though 'traditional' subsistence use is shifting to a 'modern' preference for trade. For instance, in Gnommolat District of Khammouane villagers explained how they previously ate a range of animals - pangolins, turtles, muntjac deer - but in recent years more traders came to buy wildlife so they sell them instead (Johnson et al. 2004b). Villagers continue to rely on

26 For example, wildlife meat is usually seen as tastier, cleaner and healthier than meat from domestic animals and commands a higher price even for the same kind of animal (e.g. meat from wild pig and jungle fowl is more expensive than meat from domestic pig and chicken). Elsewhere, I argue that Lao views of eating 'wild forest animals' (sat paa) represents a symbolic domestication of the 'wild forest' (paa) and is reflective of ambivalent desires for social transformation (Singh 2007).

27 Various studies show the importance of wild caught foods, including wildlife, for rural livelihoods in Laos (e.g. Clendon 2001; Foppes and Sounthone 1997; Krahn 2005).

28 Even some conservationists argue that: "[f]or conservation biology the distinction between subsistence and commercial use is irrelevant and, for management, it is severely blurred" (Hutton and Leader-Williams 2003: 220). 
other wild animals - fish, frogs, rodents, jungle fowl - but other species are "too expensive to eat!" The most common reasons given for not selling particular types wildlife are either that the species is "finished already" or "there is no buyer". In rural areas, villagers are well aware of and concerned about declines in forest resources. As another villager in the same area told me, "livelihoods are more difficult now than in the past. Now more people sell things so it is more difficult to find enough, in the past people only collected to eat. There were no buyers in the past." But reliance on wildlife and other forest products for trade is intertwined with limited options for income-generation (e.g. Bouahom et al. 2004), widespread demand from wealthier urban dwellers, and local ideas about poverty and development. While income derived from natural resources is needed for what could be considered 'non-traditional' uses, from buying medicines and school gear to batteries, radios and motorbikes, the immediate and apparent poverty of people means their concerns take moral precedence in most local settings.

The moral primacy of people's immediate livelihoods over conservation concerns is demonstrated in the reluctance of authorities to do more than give a verbal warning when sellers of wildlife are observed and confronted. At one district market in Luang Namtha in northern Laos the manager reprimanded three women for selling squirrels and bats, one of the women quickly tucked the squirrels away under the table and all laughed in an embarrassed way while the rest of the market silently looked on. The manager stormed out after telling them off and saying how it was "against the law" and my Lao friend commented that "he probably tells them off all the time." In this market as elsewhere, officials may enunciate state policy but they are averse to charging or fining sellers of wildlife in accordance with the law. A conservation project attempting to enforce a prohibition on wildlife trade in Vientiane ran into similar problems. A foreign consultant told me how officials dutifully filled out the monitoring and enforcement forms, even noting that they had returned confiscated wildlife to a market-trader after she became very upset and started crying. A Lao consultant in Vientiane noted that "people do not see animals as having rights", whereas people do have rights to collect what they can from the forest in order to eat and to live (e.g. Peluso 1996). While conservationists working in Laos support the subsistence use of wildlife by villagers, villagers in Attapeu, assert that "wildlife is something to sell, because everyone likes to buy wildlife." Given that wildlife is one of the few valuable products villagers can access and that trade-driven development receives such positive valuation as a means of livelihood improvement, prohibition of wildlife trade is readily perceived as an immoral limitation of the rights of Lao people to secure and improve their own livelihoods.

Significantly, the reluctance of officials to implement state policy in strict terms is not motivated purely by concerns for the livelihoods of villagers. It is also frequently linked to their own contravention of that same policy. For many forestry officials who at times work in relatively remote areas, one of the few perks of such assignments is the opportunity to purchase wildlife at low prices. As one official in Nakai said after returning from village surveys in a nearby protected area, "it is good to go to villages, then you can eat wildlife!" Similarly, one of the highest ranking district officials in Nakai regularly came to the village where I stayed to enjoy dishes made from squirrels, monitor lizards and more rarely muntjac deer, which was prepared by a resident trader. Yet the next-door neighbor and relative of this trader, who was also the only district official residing in the village, told me that "all wildlife hunting is illegal, even if villagers only hunt squirrels. If the district finds out, villagers will be punished." Hence, the people with the responsibility for embodying and enforcing government policies about wildlife are very likely to buy from villagers and permit the wildlife trading activities of their own family and friends. This simultaneously promotes demand, confirms the authority of officials over the use of wildlife and highlights that formal policy is always open to selective implementation. For example, when buying a civet at the Nakai district market a forestry official happily boasted, "I can buy it and the trader is not scared because I am a forestry official." ${ }^{29}$ Obviously since he was buying the trader knew she was not going to be reprimanded.

This brings me to the widely acknowledged but largely undocumented role of social position and authority. At one level this relates simply to financial requirements. Like one relatively wealthy village trader in Khammouane told me, "you need a lot of money" to trade wildlife because they are so much more expensive than fish and non-timber forest products. She explained that while many residents in her village may hunt and sell wildlife, she was the only one who could afford to buy and sell. Less obvious but just as important are the personal connections and links to different sources of authority that underlie trade. For example, during a survey of trade in natural resources in areas of Attapeu (Singh et al. 2006), provincial and district officials identified a couple of large-scale wildlife traders who were then interviewed - though with clear instructions that the traders were not to be troubled by questions that they did not want to answer. Large-scale wildlife trade may be excluded from public markets but this does not mean it occurs without public awareness or official sanction. Here emerges the second norm, the rights of elites to control

29 This was a relatively uncommon occurrence because of the scarcity of civets in that market and also because of the expense, which was usually beyond the means of low-ranking officials. 
wildlife trade, especially trade in valuable species ${ }^{30}$ or trade in large volumes (Nooren and Claridge 2001: 85-89). The inter-weaving of wildlife use and authority was most publically demonstrated in Laos when three military-operated state-owned enterprises were established in the mid-1980s to manage and develop the nation's natural resources (Stuart-Fox 2006; Walker 1999). Activities included logging, construction, agricultural development as well as wildlife trade and are acknowledged to have supported the consolidation of personal power of ranking officials. Wildlife trade associated with these enterprises would have been incidental to timber production, but wildlife was a significant indicator of authority and position above the law.

The most blatant display of this link between wildlife and personal power was by General Cheng, the former head of the notorious state-owned enterprise called BPKP, which used to operate across central Laos. $^{31}$ Just after the introduction of the 1986 ban on wildlife trade, Cheng established a zoo at his headquarters at Lak Sao in Bolikhamxai Province and stocked it with animals sourced from local villages. ${ }^{32}$ During the mid-1990s, Cheng even offered villagers US\$1,000 for the capture of a live saola, an endangered ungulate that had only just become known to biologists and was attracting worldwide scientific attention (Duckworth et al. 1999: 212; see also Dung et al. 1993). BPKP was also involved in the only case to see prosecution under the 1986 ban on wildlife trade. A forestry official in Vientiane related how his former boss in the Department of Forestry was involved in this large-scale transaction managed by BPKP and a well-connected Thai businessman. ${ }^{33}$ In 1988 the Lao president, former revolutionary leader Kaysone Phomvihane, ordered the trade stopped because "it was illegal and because of international cooperation", and also reportedly because of an internal dispute. The official described the high-profile problems they had with the confiscated animals including many birds, macaques, pythons and even three orang-utans, which are not native to mainland Southeast Asia - one of which was dramatically electrocuted on overhead wires when it escaped the forestry office in Vientiane. He explained that there was no other major wildlife trading business: "it was after the BPKP incident that wildlife trade became sensitive, before the 1986 law it was legal so then it was very open and common." While there are varied renditions of this history they all emphasize the importance of elites in the control of high-value wildlife trade (Nooren and Claridge 2001: 227-229).

In recent years, even as wildlife trade has become very sensitive and less public than the past, a huge ongoing trade in pangolins passing near Nakai suggests that such links between authority and control over wildlife persist. These scaly anteaters are collected throughout Southeast Asia for their skin and meat, and the scales are highly valued in Chinese traditional medicine (Coggins 2003). The two species of pangolins found in Laos were a decade ago "the most heavily traded animal in Lao PDR" but were being rapidly depleted (Duckworth et al. 1999: 165). Now villagers in central Laos report that numbers of Vietnamese poachers have declined as the abundance of valuable forest resources decreased, though for the preceding decade pangolins were the species that villagers most frequently reported as trading for income (Johnson et al. 2004b). ${ }^{34}$ In early 2007, pangolins were being transported overland from Malaysia through Thailand and Laos up to Lak Sao, the former headquarters of BPKP, near the Lao-Viet border. This utilized the same Lao-Viet trade route as previously (Duckworth et al. 1999; Nooren and Claridge 2001), though now pangolins are primarily sourced from Indonesia and Malaysia because the Lao populations are depleted. The traders reportedly have official papers for Thailand and Laos but not for Vietnam, so pangolins are stockpiled in huge crates at Lak Sao and then Vietnamese men are hired to walk through the Nakai-Nam Theun National Protected Area to cross the border illegally with about six pangolins in a backpack. Observers estimate that about one tonne of pangolins cross the border each day. With villagers in Laos

\footnotetext{
30 While valuable types of wildlife are not always protected and protected species are not always valuable this is often the case (Johnson et al. 2004b).

31 BPKP stands for Bolisat Kaan Patthana Khet Phou Doi meaning 'Mountainous Areas Development Company' (Singh 2007).

32 One American NGO called the Carnivore Preservation Trust (CPT), received support from Cheng to establish the zoo in Lak Sao but was later criticized by other conservationists (Nooren and Claridge 2001: 94).

33 This involved transporting wildlife from Thailand into Laos so that it could be exported to other countries as though it originated from Laos. Using Laos as a transit country took advantage of the difference in CITES coverage, as Thailand joined CITES in 1983 but Laos was not yet a member. The arrangement between BPKP, the Thai businessman and the Department of Forestry continued for a couple of years with his boss in forestry signing off on documents when he was "taken to parties and would get drunk." While the Department of Forestry is responsible for national wildlife management issues, it apparently received little economic benefit from this arrangement that mainly profited the more institutionally powerful BPKP.

34 Usually Vietnamese traders come to Laos to trade, and collect forest products, rather than Lao villagers going to Vietnam.

35 Pangolins are listed in Appendix II of CITES so their trade is permitted with appropriate permits and documentation. Since Laos, Thailand and Vietnam are all CITES members the claims to have proper papers appear false, the trader could not have the proper papers for two countries and not the other. The business interests involved and the contacts in each country more likely demanded this trade route.
} 
being paid around US\$25-35/kg for pangolins (Singh et al. 2006), this means that this pangolin trade at Lak Sao is worth in the order of US\$30,000 per day. One foreign consultant predicted that pangolins "will go from being common a few years ago to extinct in just a few years." While it is unclear who actually controls this pangolin trade, such an extensive operation could not function without the permission of highlevel Lao authorities.

The rule-of-law is acknowledged to be weak in Laos and disjunctions between official policy and everyday practice are common (Stuart-Fox 2006). Until 2003 when the relevant regulation was revised (MAF 2003), there was one open acknowledgement in official policy of the importance that authority plays in wildlife trade. Under the regulation from 2001, protected species that are prohibited for all hunting and trade could be exempted by the Prime Minister's Office (Article 17, MAF 2001). In accordance with customary tribute and exchange practices, if the animal was a gift to a foreign dignitary, it could be taken. Revision of the legislation - a requirement of the World Bank for NT2 as outlined above - lessened the power of authority over wildlife. ${ }^{36}$ Yet involvement and control by elites is still significant, only their identities remain publically unknown (Nooren and Claridge 2001: 7). Elites who control high-value wildlife trade in Laos are infrequently discussed, never mentioned in public discussions of wildlife trade, and go unnamed. The rights of elites are respected and are not open for debate. ${ }^{37}$ Instead, the needs of rural livelihoods justify the local morality of wildlife trade, although this morality is articulated with unclear distinctions between securing necessities for poor rural villagers in Laos and securing luxuries for wealthy urban residents in Laos and other countries. Popularized representations of the trade are founded on the lives of rural villagers. But at the same time, they are also politicized simplifications that evade the practice of unsustainable and inequitable trade that is controlled by elites.

\section{Conclusion}

In this article, I have shown that the social simplifications that James Scott identifies as the tools of modern statecraft, also characterize the popularized representations of wildlife trade advanced by proponents and opponents of conservation (Scott 1998). Firstly, global representations of CITES as uniting scientific and moral legitimacy overlie significant internal debates within the conservation movement about how to manage and promote wildlife trade regulation. Secondly, the politics behind the accession of Laos to CITES and recent changes to domestic policy show how conservation is often subordinate to other political concerns despite public assertions to the contrary. Thirdly, patterns of wildlife trade in Laos suggest that the moralistic construction of wildlife trade regulation as something against Lao interests neatly serves to publically obscure the high-value trade that excludes most Lao people but benefits elites. In both pro- and anti-conservation discourses, the complexity of wildlife trade tends to be reduced in standardized ways for public discussion and reproduction. Perceptions of 'right' and 'wrong' are social constructions that are subject to generalization and politicization. The immorality of unregulated trade is thus pitted against the immorality of foreign impositions. I argue that such debates, which focus the gaze outwards, are used to detract from the uncertainty and divisions that occur within. Morality is partly a response to the politicized imagining of the 'cultural other' (Harding 1991).

These observations on wildlife trade regulation in Laos thus have broader relevance for practitioners of conservation. The most evident implication is that movement towards an international consensus suggested by endorsement of global regulatory systems may be only weakly connected to changes in domestic policy and local practice. While international treaties can create an appearance of agreement about environmental management, they are products of political contingency and do not necessarily shift belief systems or replace existing decision-making frameworks. Indeed, there is a concern that tightening wildlife trade regulations may fail in terms of conservation and social goals, if international diplomacy directs implementation towards the practices of villagers and away from the elite-controlled international trade (Singh in press b). A second conclusion from this study is that the construction of global discourses may prompt outcomes and criticisms that are quite different from those prompted by implementation of specific interventions. As Li (2002: 278) notes, the social effects of conservation can be 'discursive' as well as 'material'. The discursive element is especially significant in conservation activities that are social rather than biological - for example, negotiations over international treaties, awareness-raising and the mass dissemination of conservation concerns. Attempts to promote international regulation of wildlife trade, though based on scientific evidence, are fundamentally social processes. Wider public recognition of the contestation within global discourses would be a first step towards an appreciation of the social element in conservation.

This study of wildlife trade regulation also carries implications for researchers who study the effects of conservation, and especially political ecology approaches that consider these issues as social and

\footnotetext{
36 The revised law stills allows exceptions for other reasons including scientific research and captive breeding.

37 Thus, Nooren and Claridge's (2001) review of wildlife trade in Laos was stored in boxes and not in public display in the Lao IUCN office until 2004 - when Laos joined CITES - largely because of its documentation of the involvement of officials in illegal trade.
} 
environmental concerns. Conservation has significant impacts worldwide, and these require examination (e.g. West et al. 2006). At the same time, it is necessary to maintain a critical awareness of conservation as a heterogeneous social institution. Also, even in the case of donor-dependent developing countries like Laos, international pressure to institute global conservation systems is subject to a melding of diverse political interests, some weakly related to conservation itself. Hence, conservation discourses can project an appearance of unified potency even while being effectively divided and weak. When the debates within the conservation lobby, and the politics behind policy, are made explicit then social critiques of conservation can more readily avoid any stylized simplifications of its initiatives. Political ecology rightly emphasizes the politics inherent in conservation (Adams and Hutton 2007: 147), but it must also consider the politics inherent in local resistance to conservation (Nygren 1999; Paulson et al. 2003). Furthermore, given the responsibility of social scientists to conduct social analysis, it is incumbent upon us to "bridge critique and engagement....and recogni[ze] that critique alone is not enough" (Brosius 2006: 684). Working across the social-environmental divide requires an active willingness to search for points of intersection and correspondence as well as points of variance. While there are tensions between aspirations for conservation and development, recognition of the inner complexity of the contrasts between global science and local practice and may show the way to innovative "contingent collaborations" that can connect across difference (Tsing 2005: 263).

\section{References Cited}

Adams, William M., and Jon Hutton 2007. "People, parks and poverty: political ecology and biodiversity conservation." Conservation and Society 5(2):147-183.

ADB.

2004. Cumulative Impact Analysis (CIA) and Nam Theun 2 Contributions: Final Report. Vientiane: Asian Development Bank (ADB) / Government of Lao PDR (GOL).

Adger, W. Neil, Tor A. Benjaminsen, Katrina Brown, and Hanne Svarstad. 2001. "Advancing a political ecology of global environmental discourses." Development and Anon. Change 32(4):681-715.

2004. Cooperative Action Plan Between Ha Tinh/Quang Binh (Vietnam) and Bolikhamxay/Khammouane (Lao PDR) to Control Illegal Transboundary Hunting, Trading and Transporting of Wild Fauna and Flora. Ha Tinh: Department of Forest Protection, Vietnam and Department of Forestry, Lao PDR.

Anon.

2000. Making Biodiversity Conservation Work in the Lao PDR: Some Reflections on the Feasibility Anon. of Participatory Resource Management. Vientiane.

1993. Country Review for Laos. Vientiane: Department of Forestry and Environment.

Arroyo-Quiroz, Ines, Ramon Peres-Gil, and Nigel Leader-Williams.

2005. "Developing countries and the implementation of CITES: the Mexican experience". Journal ASEAN. of International Wildlife Law and Policy 8:13-49.

2005. ASEAN Statement on Launching of the ASEAN Wildlife Law Enforcement Network (ASEAN-WEN): At The Special Meeting of the ASEAN Ministers Responsible for the Implementation of CITES, Vol. 2006. Bangkok. http://www.aseansec.org/17933.htm [cited 25 August 2006].

Bell, Sandra, Kate Hampshire, and Stella Topalidou.

2007. "The political culture of poaching: a case study from Northern Greece." Biodiversity and BBC. Conservation 16: 399-418.

BBC.

2007. Asian markets push illegal ivory. London: British Broadcasting Corporation (BBC). http://news.bbc.co.uk/2/low/science/nature/6644365.stm [cited 15 June 2007].

2004. AIDS warning over bushmeat trade. London: British Broadcasting Corporation (BBC). Black, Richard.

2007. Nations meet to protect wildlife. London: British Broadcasting Corporation (BBC). http://news.bbc.co.uk/2/low/science/nature/6715923.stm [cited 5 June 2007].

Bock, Carl.

1985. Temples and Elephants: The Narrative of a Journey of Exploration Through Upper Siam and Lao. Bangkok: White Orchid Press. 
Bouahom, Bounthong, Linkham Douangsavanh, and Jonathan Rigg.

2004. "Building sustainable livelihoods in Laos: untangling farm from non-farm, progress from distress." Geoforum 35:607-619.

Bourdet, Yves.

2000. The Economics of Transition in Laos: From Socialism to ASEAN Integration. Cheltenham:

Brack, D. Edward Elgar.

2003. "Illegal logging and the illegal trade in forest and timber products." International Forestry Review 5(3): 195-198.

Brashares, J. S.

2006. "Linking human disease risk to wildlife conservation in Cameroon." Animal Conservation 9:364-365.

Brosius, Peter J.

2006. "Common ground between anthropology and conservation biology." Conservation Biology 20(3):683-685.

CI.

2004. Leveraging SARS to reduce illegal wildlife trade in China. Conservation International (CI). CITES. http://tinyurl.com/4p6nec [cited 12 July 2007].

2007. Convention on International Trade in Endangered Species of Wild Fauna and Flora (CITES). Gland: United Nations Environment Programme (UNEP). http://www.cites.org/ [cited 10 May 2007].

Clarke, J. E. 1999. Biodiversity and Protected Areas: Lao PDR. http://tinyurl.com/4ueyel [cited 24 June 2002].

Clendon, Kate.

2001. The Role of Forest Food Resources in Village Livelihood Systems: A Study of Three Villages in Salavan Province. Vientiane: IUCN.

Coggins, Chris.

2003. The Tiger and the Pangolin: Nature, Culture, and Conservation in China. Honolulu: University of Hawai'i Press.

Cooney, Rosie, and Paul Jepson.

2006. "The international wild bird trade: what's wrong with blanket bans?" Oryx 40(1):1-6.

De Alessi, $\mathrm{M}$.

2003. Elephants, markets and mandates. Fraser Forum. http://216.219.139.105/elephantsmarkets.pdf [cited on 12 July 2007].

Delcore, D. Henry.

2004. "Symbolic politics or generification? The ambivalent implications of tree ordinations in the Thai environmental movement." Journal of Political Ecology 11: 1-30.

Dickson, Barnabas.

1999. "The precautionary principle in CITES: a critical assessment." Natural Resources Journal 39:211-228.

Duckworth, J. William, Richard E. Salter and Khamkhoun Khounboline (compilers). 1999. Wildlife in Lao PDR: 1999 Status Report. Vientiane: IUCN - The World Conservation Union / Wildlife Conservation Society / Centre for Protected Areas and Watershed Management.

Dung, Vu Van, Pham Mong Giao, Nguyen Ngoc Chinh, Do Tuoc, Peter Arctander and John MacKinnon. 1993 "A new species of living bovid from Vietnam." Nature 363:443-445.

Favre, David.

1993. "Debate within the CITES community: what direction for the future?" Natural Resources Journal 33:875-918.

Foppes, Joost and Ketphanh Sounthone.

1997. The Use of Non-Timber Forest Products. Vientiane: NTFP Project, IUCN and Department of Forestry.

Forsyth, Tim.

2003. Critical Political Ecology: The Politics of Environmental Science. London: Routledge.

Fujita, Yayoi.

2004. Political ecology of forest conservation in Laos: a case study of Phou Phanang National Reserve Forest in Lao People's Democratic Republic. Unpublished PhD thesis: Graduate School of International Cooperation, Kobe University.

Garnier, Francis. 1996. Travels in Cambodia and Part of Laos: The Mekong Exploration Commission Report (18661868) - Volume 1 (Translated by W. E. J Tips). Bangkok: White Lotus Press.

Geist, Valerius.

1988. "How markets in wildlife meat and parts, and the sale of hunting privileges, jeopardize wildlife conservation." Conservation Biology 2: 15-26. 
Gezon, Lisa L.

2006. Global Visions, Local Landscapes: A Political Ecology of Conservation, Conflict, and Control in Northern Madagascar. Lanham, MD: AltaMira Press.

Ginsberg, Joshua. GOL. 2002. "CITES at 30, or 40." Conservation Biology 16(5):1184-1191.

2004. National Growth and Poverty Eradication Strategy (NGPES). Vientiane: Government of Lao People's Democratic Republic (GOL). http://www.undplao.org/ngpes_page.htm [cited 27 April 2005].

Goldman, Michael.

2005. Imperial Nature: The World Bank and Struggles for Social Justice in the Age of Globalization. New Haven: Yale University Press.

Halpern, Joel M.

1964. Economy and Society of Laos: A Brief Survey. Yale University Southeast Asia Studies.

Halpern, Joel M.

1958. Aspects of Village Life and Culture Change in Laos. New York: Council on Economic and Cultural Affairs, Inc.

Harding, Susan.

1991. "Representing fundamentalism: the problem of the repugnant cultural other." Social Research 58(2):373-393.

Hutton, John M., and Nigel Leader-Williams.

2003. "Sustainable use and incentive-driven conservation: realigning human and conservation interests." Oryx 37(2):215-226.

IRN

IUCN.

2004. Dams in Laos: On the Record. Berkley: International Rivers Network (IRN).

2007. IUCN Red List of Threatened Species, Vol. 2007: The World Conservation Union (IUCN). www.iucnredlist.org/ [cited on 12 July 2007].

IUCN.

2000. "Lao PDR Country Profile". In The World Commission on Protected Areas $2^{\text {nd }}$ Southeast Asia Regional Forum, 6-11 December, 1999, Pakse, Lao PDR, A. Galt, T. Sigaty and M. Vinton (eds.). Vientiane: IUCN

IUCN.

1999. Nakai-Nam Theun Conservation Area Programme Phase 2: Community Development and Biodiversity Conservation. Vientiane: The World Conservation Union (IUCN).

IUCN

1998. The IUCN Programme in Lao PDR. Vientiane: The World Conservation Union (IUCN).

Izikowitz, Karl G.

1979. Lamet: Hill Peasants in French Indochina. New York: AMS Press.

Johnson, Arlyne, Sarinda Singh, and Malaykham Dongdala

2004a. Wildlife hunting and use in Luang Namtha Province: implications for rural livelihoods and biodiversity conservation in the uplands of Lao PDR. In Shifting Cultivation and Poverty Eradication in the Uplands of the Lao PDR. Vientiane: National Agriculture and Forestry Research Institute (NAFRI)

Johnson, Arlyne, Ramesh Boonaratana, Guy Marris, and Sarinda Singh. 2004b. Ground-based Inventory of Human Activity in the Peripheral Impact Zones of the NakaiNam Theun National Protected Area: Synthesis Report. Vientiane: World Bank.

Jones, Samantha.

2006. "A political ecology of wildlife conservation in Africa." Review of African Political Economy 109:483-495.

Karesh, William B., Robert A. Cook, Elizabeth L. Bennett, and James Newcomb. 2005. "Wildlife trade and global disease emergence." Emerging Infectious Diseases 11(7):10001002.

Krahn, Jutta.

2005. The dynamics of dietary change of transitional food systems in tropical forest areas of Southeast Asia: the contemporary and traditional food system of the Katu in the Sekong Province, Lao PDR. Hohen Landwirtschaftlichen Fakultat: Rheinischen Friedrich-Wilhelms-Universitat.

Krahn, Jutta, and Arlyne Johnson.

2007. "Upland food security and wildlife management." Juth Pakai (New Thought) 9:17-33.

Lewis, Michael. 2005. "Indian science for Indian tigers?: conservation biology and the question of cultural values." Journal of the History of Biology 38:185-207.

Lewis, Dale M., and Peter Alpert. 1997. "Trophy hunting and wildlife conservation in Zambia." Conservation Biology 11: 59-68. 
Li, Tania M.

MAF.

2002. "Engaging simplifications: community-based resource management, market processes and state agendas in upland Southeast Asia." World Development 30(2): 265-83.

2001. Regulation on the management of the National Biodiversity Conservation Areas (NBCA), Aquatic and Wild Animals, Decree No.0524/AF.2001. Vientiane: Ministry of Agriculture and Forestry (MAF).

MAF.

2003. National Biodiversity Conservation Areas, Aquatic and Wild Life Management Regulations, Decree No.0360/AF.2003. Vientiane: Ministry of Agriculture and Forestry (MAF).

Ngaosrivathana, Mayoury, and Pheuiphanh Ngaosrivathana.

2001. Vietnamese Source Materials Concerning the 1827 Conflict between the Court of Siam and the Lao Principalities: Journal of Our Imperial Court's Actions With Regard to the Incident Involving the Kingdom of Ten Thousand Elephants. Tokyo: Centre for East Asian Cultural Studies for UNESCO.

McGirk, Jan.

2004. Thailand bans theme park's orang-utan boxing bouts. Bangkok: The Independent. http://tinyurl.com/4cdhpd [cited on 12 July 2007].

Miyaoka, Isao.

2004. Legitimacy in International Society: Japan's Reaction to Global Wildlife Preservation. Hampshire: Palgrave Macmillan.

Nash, Stephen, and Steven Broad.

1993. Accession of Lao PDR to CITES and other conservation treaties. Vientiane: Lao-Swedish Forestry Cooperation Programme / IUCN.

Nooren, Hanneke, and Gordon Claridge.

2001. Wildlife Trade in Laos: The End of the Game. Amsterdam: Netherlands Committee for IUCN.

Nygren, Anja.

1999. "Development discourses and peasant-forest relations: natural resource utilization as social process." Development and Change 31:11-34.

Paulson, Susan, Lisa L. Gezon, and Michael Watts.

2003. "Locating the political in political ecology: an introduction." Human Organization 62(3):205217.

Pearl, Mary C.

2004. "Wildlife trade: threat to global health." EcoHealth 1: 111-112.

Peluso, Nancy Lee.

1996. "Fruit trees and family trees in an anthropogenic forest: ethics of access, property zones, and environmental change in Indonesia." Comparative Studies in Society and History 38(3):510-548.

Redford, Kent H.

Reuters.

1992. "The empty forest." Bioscience 42:412-422.

2007. Southeast Asia seeks to crack down on animal trade. Reuters News Service. http://www.enn.com/today.html?id=12815 [cited 23 May 2007].

Robichaud, William.

2002. Biodiversity of the Nakai-Nam Theun National Protected Area and the Nakai Plateau, Lao PDR. Vientiane: Nam Theun 2 Electricity Consortium.

Robinson, John G. and Elizabeth L. Bennett. 2000. Hunting for Sustainability in Tropical Forests. New York: Columbia University Press.

Ryder, Grainne.

2004. Ten Reasons Why the World Bank Should Not Finance the Nam Theun 2 Power Company in Lao PDR. Toronto: Probe International. http://www.eprf.ca/pi/documents/mekong/nt10reasons.pdf[cited 5 May 2005].

Sand, Peter H.

1997. Whither CITES? "The evolution of a treaty regime in the borderland of trade and environment." European Journal of International Law 8(1):29-58.

Sautner, Steve, John Delaney, and Melvin Gumal. 2005. Asia's biodiversity vanishing into the marketplace. Wildlife Conservation Society (WCS). http://www.wcs.org/353624/191919 [cited 2 May 2005].

Sautner, Steve, Elizabeth L. Bennett, and Antony Lynam. 2002. Greatest threat to Asia's wildlife is hunting, scientists say. Wildlife Conservation Society (WCS). http://tinyurl.com/4pfrb2 [cited 30 June 2004].

Sayer, J.

1983. Forest Management Project, Lao People's Democratic Republic: Nature Conservation and National Parks. Vientiane: Food and Agriculture Organization of the United Nations (FAO). 
Scott, James C.

1998. Seeing Like a State: How Certain Schemes to Improve the Human Condition Have Failed. New Haven: Yale University Press.

Scudder, Thayer, Lee M. Talbot and Tim C. Whitmore. 1997. Nam Theun 2 Hydro Project: Report of the International Environmental and Social Panel of Experts. Vientiane: Ministry of Industry and Handicraft.

Singh, Sarinda, Ramesh Boonratana, Mark Bezuijen and Aloun Phonvisay. 2006. Trade in Natural Resources in Attapeu Province, Lao PDR: An Assessment of the Wildlife Trade. Vientiane: TRAFFIC / MWBP (Mekong Wetlands Biodiversity Conservation and Sustainable Use Programme).

Singh, Sarinda.

2007. A state of uncertainty: interpretations of forests and wildlife in Laos. Unpublished PhD thesis: Research School of Pacific and Asian Studies, Australian National University.

Singh, Sarinda

In press a. "Living within the state: a dormitory community in central Laos." In Spirits, States and Scooters: Tai Communities on the Move, A. Walker (ed.). Singapore: National University of Singapore Press.

Singh, Sarinda.

In press b. "Social challenges to integrating conservation and development: the case of wildlife use in Laos." Society and Natural Resources.

Sodikoff, Genese.

2007. "An exceptional strike: a micro-history of 'people verus park' in Madagascar." Journal of Political Ecology 14:10-33.

Srikosamatara, S. and V. Suteethorn. 1994. "Wildlife conservation along the Thai-Lao border." Natural History Bulletin of the Siam Society 42:3-21.

Stoett, Peter.

2005. "Of whales and people: normative theory, symbolism, and the IWC." Journal of International Wildlife Law and Policy 8: 151-75.

Stoett, Peter.

2002. "The international regulation of trade in wildlife: institutional and normative considerations." International Environmental Agreements: Politics, Law and Economics 2: 195-210.

Stuart-Fox, Martin.

2006. "The political culture of corruption in the Lao PDR." Asian Studies Review 30:59-75.

Stuart-Fox, Martin.

2004. Politics and Reform in the Lao People's Democratic Republic. Political Economy of Development, Working Paper No.1. Williamsburg: Program on Civil Society and Governance, The College of William and Mary.

Thorbjarnarson, John.

1999. "Crocodile tears and skins: international trade, economic constraints, and limits to the sustainable use of crocodilians'." Conservation Biology 13: 465-470.

TRAFFIC.

2004a. ASEAN Wildlife Trade Initiative. TRAFFIC.

TRAFFIC. http://www.traffic.org/25/network9/ASEAN/index.html [cited 28 April 2005].

2004b. Better signals needed on wildlife trade super-highway. WWF and IUCN. http://www.traffic.org/news/press-releases/better_signals.html [cited 2 May 2005].

TRAFFIC and WWF.

2003. TRAFFIC and WWF commend Lao PDR's decision to join CITES. TRAFFIC and WWF. http://tinyurl.com/49qra8 [cited 2 May 2005].

Tsing, Anna Lowenhaupt.

2005. Friction: An Ethnography of Global Connection. Princeton: Princeton University Press.

Tung, D.

2004. Launch of 'National Action Plan to Strengthen the Control of Trade in Wild Fauna and Flora to 2010'. TRAFFIC. http://www.trafficindo.org/press_release\%20nap\%20approved.htm [cited 2 UNDP. May 2005]

2003. Draft Minutes: The Second Biodiversity Conservation Forum of the Kingdom of Cambodia, UNDP. Laos PDR and SR Vietnam. Vientiane: United Nations Development Programme (UNDP).

1993. Sub-Regional Project: Biodiversity Conservation Component: Project Document. United Nations Development Programme (UNDP). 
US Department of State.

2007. Combating Global Illegal Wildlife Trade a U.S. Priority. http://tinyurl.com/4awbk7 [cited on 27 July 2007].

US Department of State.

2005. United States Forms Global Coalition Against Wildlife Trafficking. http://usinfo.state.gov/gi/Archive/2005/Sep/26-653558.html?chanlid=globalissues [cited on 10 May VNA. 2006].

2005a. Viet Nam-Laos joint declaration issued. Vietnam News Agency (VNA).

http://www.vnagency.com.vn/NewsA.asp?LANGUAGE_ID=2\&CATEGORY_ID=29\&NEWS_ID

VNA. $=144287$ [cited 2 May 2005].

2005b. Viet Nam, Laos discuss border markets. Vietnam News Agency (VNA). http://www.vnagency.com.vn/newsA.asp?LANGUAGE_ID=2\&CATEGORY_ID=29\&NEWS_ID= 135879 [cited 2 May 2005].

Walker, Andrew.

1999. The Legend of the Golden Boat: Regulation, Trade and Traders in the Borderlands of Laos, Thailand, China and Burma. Surrey: Curzon.

Wallington, Tabatha J., and Susan M Moore.

2005. "Ecology, values, and objectivity: advancing the debate." BioScience 55(10):873-878.

WCS and TRAFFIC.

2004. Hunting and Wildlife Trade in Asia. Bali, Indonesia: Wildlife Conservation Society (WCS) and TRAFFIC.

West, Paige, James Igoe, and Dan Brockington.

2006. "Parks and peoples: the social impact of protected areas." Annual Review of Anthropology WildAid. $35: 251-277$

World Bank.

2007. WildAid. http://www.wildaid.org/ [cited 12 July 2007].

2005. Nam Theun 2 Hydroelectric Project Overview. World Bank. http://tinyurl.com/3osrcm

World Bank. [cited 2 May 2005].

2004. Cooperation - not wildlife - across the borders: Governments of Lao PDR, Vietnam sign new agreement on transboundary trade. World Bank. http://tinyurl.com/3wazlx [cited 2 May 2005].

World Bank.

2000. Aide Memoire: Nam Theun Social and Environmental Project Logging and Watershed WWF. Management Mission. Vientiane: World Bank.

2007. Help end the tiger trade. Worldwide Fund for Nature. http://tinyurl.com/3v3emb [cited 12 July 2007].

Yongge, Su.

2000. "Ecology without borders." In Where China Meets Southeast Asia: Social and Cultural Change in the Border Regions, G. Evans, C. Hutton and K. K. Eng (eds.). New York: St Martin's Press.

\begin{abstract}
This article examines the intricacy within stylized debates that surround conservation and the regulation of wildlife trade in Southeast Asia. Illegal and unregulated trade in wildlife has been characterized by conservation groups as a great risk for wildlife worldwide and the prime threat for remaining wildlife populations in Laos. The Convention on International Trade in Endangered Species (CITES) is the centrepoint of the global discourse on wildlife trade. Popular representations of wildlife trade promoted by conservation organizations construct an image of regulation through CITES as a global necessity. The assumed morality of such interventions can provoke counter accusations about the immorality of impositions by Western conservationists. Yet both of these competing representations of wildlife trade regulation encourage externally-focused moralized debates that obscure the internal dynamics within global conservation, national policy formation and local practice. Recognition of the simplifications that characterize these three domains cautions against any idealized contrast between global hegemony and local resistance in critical studies of conservation. Instead, the focus becomes the contestation that is often hidden within such dichotomies.
\end{abstract}

Keywords: Conservation, wildlife, Lao PDR, CITES 


\section{Résumé}

Cet article examine la complexité des débats qui entourent la conservation et la réglementation du commerce des espèces sauvages en Asie du Sud-Est. Illégale et non réglementée, le commerce des espèces sauvages a été caractérisée par des organismes de conservation comme un grand risque pour la faune du monde entier et le premier menace pour des animaux sauvages au Laos. La "Convention on International Trade in Endangered Species"(CITES) est le point central du discours sur le commerce des espèces sauvages. Représentations populaires du commerce des espèces sauvages construire une image de la réglementation par la CITES comme une nécessité mondiale. Celle-ci peuvent provoquer quelques contreaccusations sur l'immoralité d'imposition par les conservateurs occidentaux. Pourtant, ces deux représentations concurrentes de la faune encourager la réglementation du commerce extérieur masquer la dynamique interne à l'échelle mondiale de conservation, la politique nationale, et les pratiques locales. Reconnaissance des simplifications qui caractérisent ces trois domaines met en garde dans les études critiques de la conservation un l'idéalisation d'un contraste entre hégémonie mondiale et la résistance locale. Au lieu de cela, l'accent de cet article est la contestation souvent caché au sein de ces dichotomies.

Mots-clés: Conservation, la faune, République Démocratique Populaire Lao, CITES.

\section{Resumen}

Este artículo examina la complejidad dentro de estilizada debates que rodean la conservación y la regulación del comercio de especies silvestres en el sudeste de Asia. Ilegal y no regulada en el comercio de vida silvestre se ha caracterizado por grupos conservacionistas como un gran riesgo para la vida silvestre en todo el mundo y la principal amenaza para el resto de poblaciones de vida silvestre en Laos. La "Convention on International Trade in Endangered Species" (CITES) es el punto central del discurso global sobre el comercio de vida silvestre. Popular representaciones de comercio de vida silvestre promovida por organizaciones de conservación construir una imagen de la regulación a través de la CITES como una necesidad mundial. El asumió la moral de este tipo de intervenciones pueden provocar contrarrestar las acusaciones sobre la inmoralidad de imposiciones por los conservacionistas occidentales. Sin embargo, ambos compiten representaciones de la regulación del comercio de vida silvestre fomentar el exterior-se centró moralized debates que perder de vista la dinámica interna dentro de la conservación global, la política nacional y la formación práctica local. El reconocimiento de las simplificaciones que caracterizan a estos tres dominios advierte contra cualquier idealizada contraste entre la hegemonía mundial y la resistencia local en estudios críticos de la conservación. En lugar de ello, el enfoque se convierte en la impugnación que a menudo se oculta dentro de esas dicotomías.

Palabras clave: Conservación, la vida silvestre, la República Democrática Popular Lao, CITES 